Instytut Historii Sztuki, Katedra Historii Sztuki Wczesnochrześcijańskiej i Tradycji Antycznej, Katolicki Uniwersytet Lubelski

\title{
Późnoantyczne tkaniny jedwabne z Achmim w zbiorach Muzeum Uniwersytetu Jagiellońskiego w Krakowie*
}

\section{ABSTRACT \\ Late Antique silk fabrics from Akhmim in the collection of the Jagiellonian University Museum in Kraków}

The paper presents so-far unpublished fragments of Late Antique silk fabrics in the Jagiellonian University Museum (MUJ). According to the archival documentation they derive from the collection of the Alsatian archaeologist, Robert Forrer (1866-1947), who was one of the pioneering collectors and dealers in Late Antique textiles from Egypt. Silks in the MUJ belong to the group of "Zachariasstoffe", said to be found in Akhmim in Upper Egypt. Parallel fragments can be found in many European and American museums.

Keywords: Late Antique textiles from Egypt, silk, "Zachariasstoffe”, Akhmim, Robert Forrer

Słowa kluczowe: późnoantyczne tkaniny z Egiptu, jedwab, „Zachariasstoffe”, Achmim, Robert Forrer

W zbiorach Muzeum Uniwersytetu Jagiellońskiego w Krakowie znajduje się 99 fragmentów tkanin późnoantycznych z Egiptu. Nie zostały one dotychczas dokładnie zbadane i tylko niektóre z nich są opublikowane ${ }^{1}$. Mniej więcej połowa tkanin, które są w posiadaniu Muzeum (numery inw. MUJ 750/1-MUJ 750/51) to fragmenty przyszyte

* Serdecznie dziękuję Pani kurator Joannie Sławińskiej i Pani konserwator Magdalenie Naruszewicz za nieocenioną, wykraczającą znacznie poza zwykłe obowiązki, pomoc w zebraniu informacji o tkaninach w Muzeum Uniwersytetu Jagiellońskiego. Dziękuję również Panu dr. Robertowi Hesiowi 
do kart dużej $(51,6 \mathrm{~cm} \times 35,5 \mathrm{~cm})$ księgi, tworzącej rodzaj albumu z ,próbkami” tka$\mathrm{nin}^{2}$. Jak informuje stary inwentarz Gabinetu Archeologicznego UJ, ,materye z grobów chrześcijańskich (...), oprawione w księgę” zakupiono w 1893 roku ,z uposażenia Gabinetu". Wprawdzie dokumentacja MUJ nie zawiera żadnych wskazówek co do proweniencji księgi, jednak analogie z tkaninami o udokumentowanej proweniencji w innych muzeach wskazywały na trop prowadzący do Roberta Forrera (1866-1947) - alzackiego archeologa, kolekcjonera i antykwariusza, związanego z Muzeum Archeologicznym w Strasbourgu ${ }^{3}$. Przebadanie pozostawionej przez Forrera i przechowywanej w archiwach strasburskiego muzeum dokumentacji prowadzonych przez niego transakcji potwierdziło przypuszczenie, że to z jego kolekcji pochodzi 51 tkanin w księdze w MUJ . Druga część obecnej kolekcji późnoantycznych tkanin w Muzeum Uniwersytetu Jagiellońskiego (numery inwentarzowe: MUJ 1234/1-MUJ 1240/13), przechowywana jest w specjalistycznej szafie z poziomo umieszczonymi w nich ekranami z napiętego płótna, do którego przymocowane są wycinki materiałów (nie tylko późnoantycznych, ale także z innych epok). Niesprawdzoną dotychczas informację z kart muzealnych: ,,pozyskane do zbiorów MUJ po 1945 roku (prawdopodobnie ze składnicy muzealnej na Wawelu)”, potwierdziła kwerenda przeprowadzona w archiwum na Wawelu, gdzie wśród dokumentacji transportów dzieł sztuki z terenów Dolnego Śląska zachował się protokół otwarcia skrzyń przywiezionych do Krakowa ze stacji kolejowej Duszniki-Zdrój w dniu 22 września 1945 roku. Wśród wymienionych w protokole obiektów znajduje się m.in. „szafa nr 283 z napisem

z Archiwum Muzeum Narodowego we Wrocławiu oraz Pani prof. Bernadette Schnitzler z Muzeum Archeologicznego w Strasbourgu za pomoc w kwerendach archiwalnych.

${ }^{1}$ Najsolidniejszym opracowaniem tkanin późnoantycznych z Egiptu będących w posiadaniu polskich muzeów pozostaje ciągle - mimo potrzeby uaktualnienia niektórych informacji - publikacja S.J. Gąsiorowskiego, Późnohellenistyczne $i$ wczesnochrześcijańskie tkaniny egipskie w zbiorach polskich, „Prace Komisji Historii Sztuki PAU” 1928, z. 4, s. 231-292. W artykule tym omówiona została część tkanin z MUJ: s. 248n (il. 11), s. 255n (il. 19), s. 257n (il. 22 i 23), s. 260n (il. 26), s. 261 (il. 27), s. 263-265 (il. 29, 30 i 30), s. 274 (il. 41 i 42), s. 277 (il. 50), s. 284 (il. 60), s. 285 (il. 61). W ostatnich latach profesor Janusz A. Ostrowski poświęcił kolekcji tkanin późnoantycznych w MUJ artykuł, w którym dostarcza czytelnikowi ogólnych informacji na temat późnoantycznych tkanin z Egiptu, jednak nie ma w tej publikacji szczegółowych informacji dotyczących konkretnie tkanin z kolekcji MUJ vide Antyczne tkaniny znad Nilu w zbiorach Uniwersytetu Jagiellońskiego [w:] Egipt, Grecja, Italia... Zabytki starożytne z dawnej kolekcji Gabinetu Archeologicznego Uniwersytetu Jagiellońskiego, red. J. Śliwa, Kraków 2007, s. 188-192.

2 Tego rodzaju eksponowanie tkanin w formie albumów było w końcu XIX i na początku XX w. dość powszechną praktyką - vide Th.K. Thomas, From curiosities to objects of art: modern reception of Late Antique Egyptian textiles as reflected in Dikran Kelekian's Textile Album of ca. 1910 [w:] Anathemata eortika: studies in honor of Thomas F. Mathews, red. J. Alhermes, Mainz 2009, s. 306. Albumy takie przybierać mogły różne formy. Wyjątkowym przykładem, stanowiącym właściwie samo w sobie dzieło sztuki, jest dwutomowe dzieło z 1913 r., zawierające kolekcję tkanin (i akcesoriów) pochodzących z wykopalisk Alberta Gayeta w Antinoopolis, przymocowanych na kartach księgi w aranżacjach o dużym walorze estetycznym i uzupełnionych opracowaniem Gayeta dotyczącym znalezisk z Antinoopolis - vide N.A. Hoskins, The Coptic Tapestry Albums and the archaeologist of Antinoé, Albert Gayet, Seattle-London 2004.

3 B. Schnitzler, Robert Forrer (1866-1947), Archéologue et antiquaire, Strasbourg 1999.

${ }^{4}$ Przechowywany w archiwum Muzeum Archeologicznego w Strasbourgu notes „Verkaufs und Einkaufs und Notizbuch über Koptische Stoffe - Geschäft Achmim”. 
Schrank «C». Próbki tkanin od koptyjskich po początek XIX w.” (z odręcznym dopiskiem „spis niemiecki załączony”) ${ }^{5}$. Dalsze badania pozwoliły ustalić, że przed drugą wojną światową szafa z tkaninami należała do Schlesisches Museum für Kunstgewerbe und Altertümer we Wrocławiu. Jak można wnioskować z zachowanych przy tkaninach oryginalnych metryczek z pierwotnymi numerami inwentarzowymi, w których zastosowano system uwzględniający datę nabycia, interesujące nas tkaniny późnoantyczne zakupione zostały w latach 1890, 1891 i 1897. Większość inwentarzy i kart ewidencyjnych Kunstgewerbemuseum przepadła w wojennej zawierusze, szczęśliwie ocalała jednak część z nich ${ }^{6}$, pozwalająca wskazać źródło zakupu z 1890 roku oraz miejsce pochodzenia niektórych z pozyskanych wówczas do muzeum tkanin 7 . Zakupu dokonano u wspomnianego już wyżej Forrera. Był on jedną z najważniejszych postaci w historii kolekcjonerstwa tkanin późnoantycznych, a pochodzące z jego zbiorów egzemplarze znajdują się obecnie w wielu muzeach europejskich ${ }^{8}$. Stanowiskiem archeologicznym, z którego pozyskał większość swoich tkanin, było Achmim ${ }^{9}$. Miasto to figuruje też w kartach ewidencyjnych Schlesisches Museum für Kunstgewerbe und Altertümer jako miejsce pochodzenia trzech spośród sześciu tkanin jedwabnych stanowiących obecnie część zbiorów Muzeum Uniwersytetu Jagiellońskiego (il. I-VI) ${ }^{10}$.

W niniejszym artykule omówiona zostanie specyfika Achmim jako stanowiska archeologicznego będącego jednym z najważniejszych źródeł pochodzenia tkanin późnoantycznych, w tym również tkanin jedwabnych o charakterystycznej dekoracji. Następnie opisane zostaną najbardziej reprezentatywne dla tej grupy zabytków egzemplarze z kolekcji europejskich i amerykańskich, i wreszcie na tym tle usytuowane zostaną fragmenty w posiadaniu Muzeum Uniwersytetu Jagiellońskiego.

\footnotetext{
5 Archiwum na Zamku Wawel, teczka opisana: „Restytucje mienia państwowego. Transporty powojenne z terenów Dolnego Śląska 21.06-9.12.1945 oraz transporty z Norymbergi 2.05.1946”; a także teczka „Restytucje mienia państwowego. Zwrot obiektów zabytkowych przechowywanych na Wawelu do instytucji krakowskich (muzea, instytucja naukowe)".

${ }^{6}$ Dwadzieścia dwie karty z przypiętą karteczką „koptyjskie fajumskie 22 sztuki z zakupu 1890”, przy czym jedna z nich to karta chińskiej tkaniny z XV w., a jedna - tkaniny francuskiej z XVIII w., zakupionej w 1895 r. (na wszystkich jednak kartach jako źródło zakupu podaje się nazwisko Roberta Forrera). Karty przechowywane są w Archiwum Muzeum Narodowego we Wrocławiu.

${ }^{7}$ Informacje z kart potwierdza i uzupełnia notka w Schlesiens Vorzeit in Bild und Schrift 5 (1894): 58-6, która wspomina o zakupie w 1890 r. „63 Nummer koptischer Gewebe aus den Textilfunden in den Nekropolen zu Achmim und Fajium".

8 Znaczenie Forrera dla formowania się wczesnych kolekcji podkreśla m.in. L. Török (Coptic Antiquities, vol. 2: Textiles, Roma 1993, s. 13): „There can be no doubt that not only his own publications, but also Forrer's sales of both large and small groups of textiles, composed with certain didactical and historical considerations in mind, have greatly contributed to the constant rise of professional and public interest towards the art of post-pharaonic Egypt".

${ }^{9}$ C. Fluck, Akhmim as a source of textiles [w:] Christianity and monasticism in Upper Egypt 1: Akhmim and Sohag, red. G. Gabra, H. Takla, Cairo 2008, s. 213-215.

${ }^{10}$ Karty pozostałych trzech tkanin jedwabnych nie zachowały się, na podstawie udokumentowanych analogii do innych kolekcji można jednak przypuszczać, że przynajmniej jedna z nich również pochodzi z Achmim - vide dalej.
} 
Późnoantyczne tkaniny z Egiptu, zwane czasami w starszej literaturze „koptyjskimi”"11, kojarzą się przede wszystkim z wełnianymi tapiseriami na osnowie lnianej ${ }^{12}$. Istotnie, len i wełna były najczęściej używanymi w późnoantycznym Egipcie surowcami, wykorzystywanymi zarówno do produkcji odzieży, jak i tekstyliów „wnętrzarskich” (obrusów, zasłon, kilimów, narzut na łóżka, koców, poduszek, dywanów itd. $)^{13}$. Z późnoantycznych grobów w Egipcie trafiały jednak do muzealnych kolekcji również tkaniny jedwabne, choć jest ich stosunkowo niewiele ${ }^{14}$. Część z odnalezionych w Egipcie tkanin jedwabnych to importy, np. z Persji ${ }^{15}$. Badacze uważają jednak, że tkaniny jedwabne mogły być też wytwarzane ze sprowadzanego surowca w miejscowych, egipskich warsztatach ${ }^{16}$, a jednym z ośrodków produkcji tkanin jedwabnych w Egipcie było prawdopodobnie Achmim ${ }^{17}$.

Achmim położone jest w Górnym Egipcie, ok. $450 \mathrm{~km}$ na południe od Kairu, na wschodnim brzegu Nilu ${ }^{18}$. W czasach faraońskich miasto, noszące wówczas nazwę Khent-Min, było stolicą dziewiątego nomu górnoegipskiego i ważnym ośrodkiem kultu boga płodności, Mina. Grecy, utożsamiający Mina z Panem, przemianowali Khent-Min, zwane wówczas z grecka Chemnis, na Panopolis. Tej nazwy używali również Rzymianie,

${ }^{11}$ Obecnie unika się tego określenia lub bierze się je w cudzysłów, ponieważ jego etniczno-religijne konotacje w odniesieniu do zabytków późnoantycznych często bywają nieadekwatne, nieprecyzyjne lub wręcz mylące. W wypadku tkanin sytuacja jest jeszcze bardziej skomplikowana, ponieważ zagrzebane w piaskach egipskiej pustyni szaty czy tkaniny użytkowe mogły być importami, np. z Persji. Vide np. A. Stauffer, Textiles of late Antiquity, New York 1995, s. 5; Th.K. Thomas, Egyptian art of late antiquity [w:] A companion to ancient Egypt, red. A.B. Llloyd, New York 2010, s. 1062.

12 Od początku podkreślano mistrzostwo, jakie osiągnęła w tej dziedzinie sztuka „koptyjska”. Już w 1890 r. ówczesny dyrektor manufaktury gobelinów, Edouard Gerspach, poświęcił im wydaną w Paryżu publikację Les Tapisseries Copte, dodając we wprowadzeniu, że niektórzy nazywają te tkaniny „koptyjskimi gobelinami” - E. Gerspach, Les Tapisseries Copte, Paris 1890, s. 1.

${ }_{13} \mathrm{~W}$ znaleziskach z Egiptu spotyka się również inne techniki tkackie z zastosowaniem lnu i wełny, np. płótna bouclé z krótką lub długą okrywą pętelkową, dwustronne wełniane taqueté o wzorze raportującym, broszowanie, zdarzają się też - choć rzadko - tkaniny malowane i drukowane, a także haftowane. Ogólne informacje na temat materiałów i technik tkackich stosowanych w Egipcie w epoce późnoantycznej - vide C. Fluck, G. Helmecke, Egypt's post-pharaonic textiles [w:] Coptic civilization: two thousand years of Christianity in Egypt, red. G. Gabra, Cairo 2012, s. 244-246 - ibidem odwołania do bardziej szczegółowych opracowań poszczególnych materiałów i technik. Na temat źródeł pisanych $\mathrm{i}$ archeologicznych do poznania przemysłu tkackiego w Egipcie - vide E. Wipszycka, L'industrie textile dans l'Egypte romaine, Wrocław 1965.

${ }^{14}$ R. Forrer (Die römischen und byzantinischen Seidentextilien aus dem Gräberfelde von Achmim-Panopolis. Strassburg 1891 - dalej cyt.: Seiden - s. 10) szacuje, że „zaledwie jedna jedwabna tkanina przypada na kilkaset wełnianych”. Sam posiadał wówczas ok. 100 jedwabnych tkanin w swojej kolekcji.

${ }_{15}$ Sporo perskich tkanin jedwabnych odkryto w Antinoe - vide np. R. Pfister, Le Rôle de l'Iran dans les textiles d'Antinoé, ,Ars Islamica” 1948, vol. 13, s. 46-74; A. Geijer, A silk from Antinoe and Sasanian textile art, „Orientalia Suecana” 1963, vol. 12, s. 3-36.

${ }^{16}$ E. Wipszycka, op. cit., s. 37-39.

17 O. von Falke, Kunstgeschichte der Seidenweberei, Berlin 1913, s. 43; C. Fluck, G. Helmecke, op. cit., s. 244. Kontrowersje na temat istnienia lokalnych warsztatów produkujących tkaniny jedwabne - vide A. de Moor, S. Schrenk, C. Verhecken-Lammens, New research on the so-called Akhmim Silks [w:] Texiles in situ: Their find Spots in Egypt and neighbouring countries in the First Millennium, red. S. Schrenk, Riggisberg 2006, s. 85-94.

${ }^{18}$ Po drugiej stronie rzeki leży Sohag ze słynnym Białym i Czerwonym Klasztorem. 
w języku koptyjskim przetrwała jednak dawna nazwa (Shmin), która następnie w arabskim przyjęła formę Achmim (Akhmim) ${ }^{19}$.

Niewiele zachowało się zabytków świadczących o dawnej świetności miasta - archeolodzy zidentyfikowali zaledwie szczątki świątyń i innych miejskich zabudowań ${ }^{20}$. Wśród archeologów i historyków sztuki Achmim słynie jednak nie tyle za sprawą pozostałości samego miasta, ile z powodu jego nekropoli. W ciągu kolejnych stuleci - i tysiącleci - swojego istnienia miasto obrosło cmentarzami, na których sąsiadują ze sobą, a czasami nawarstwiają się, pochówki z epoki przeddynastycznej, faraońskiej, greckiej, rzymskiej, późnoantycznej, a następnie - z czasów arabskich ${ }^{21}$. Jak pisał Gaston Maspero - pierwszy egiptolog, który systematycznie zaczął badać to miejsce: „Żaden cmentarz starożytny nie zasługuje bardziej na miano «nekropoli» niż Achmim: jest to zaprawdę miasto, którego mieszkańców liczy się w milionach"22.

O mieście i jego nekropoli wspominają podróżnicy europejscy już w XVIII wieku ${ }^{23}$, ale jednym z najbardziej eksplorowanych stanowisk w Egipcie stało się ono dopiero pod koniec XIX stulecia. Wówczas pustynne piaski zaczęto przeczesywać głównie pod kątem pochówków późnoantycznych, bogatych w tkaniny, których kolekcjonowanie stało się w tym czasie niezwykle modne, w związku z czym popyt na nie był ogromny $\mathrm{i}$ ich poszukiwania wszczęto na szeroką skalę ${ }^{24}$. Ten wielki boom na tkaniny późnoantyczne

${ }^{19}$ H. Leclerq, Akhmin [w:] DACL, t. I, cz. 1, Paris 1907, kol. 1042-1046; K. Kuhlmann, Akhmìm [w:] Enciclopedia dell'Arte Medievale, http://www.treccani.it/enciclopedia/akhmim_\%28Enciclopedia-dell\%27-Arte-Medievale\%29/ [dostęp: 14.08.2018] - ibidem wykaz starożytnych źródeł i wyczerpująca bibliografia. Najbardziej kompleksowa i aktualna monografia Achmim w epoce rzymskiej i późnoantycznej (do 600 r.) to rozprawa doktorska K. Geens, Panopolis, a Nome Capital in Egypt in the Roman and Byzantine Period (ca. AD 200-600), Leuven 2014, dostępna na stronie Trismegistos Online Publications, https://www.trismegistos.org/top.php [dostęp: 14.08.2018].

${ }^{20}$ Geens, op. cit., s. 15-22.

${ }^{21}$ Topografię nekropoli achmimskiej uporządkował N. Kuhlmann, który w latach 70.-80. XX w. prowadził tam wykopaliska. Podzielił rozległe cmentarzysko na trzy regiony: A - grobowce skalne i ziemne w dolinie bliżej miejscowości Al.-Hawawish, ok. $3 \mathrm{~km}$ od Achmim; B - grobowce skalne w klifach El-Salamuni, ok. 6 km na północ od Achmim; C - grobowce skalne w klifach El-Hawawish, ok. $6 \mathrm{~km}$ na wschód od miasta. Wszystkie trzy cmentarze zawierają pochówki z czasów faraońskich, natomiast w regionie A i C są też groby z innych epok. Najwięcej tkanin w początkowym okresie wykopalisk dostarczył rejon El-Hawawish - vide N. Kuhlman, Materialien zur Archäologie und Geschichte des Raumes von Achmim, SDAIK 11, 1983, s. 50-86. Na temat nekropoli i historii jej badań - vide również K. Geens, Panopolis..., Trismegistos 2014, s. 31-49.

${ }^{22}$ G. Maspero, Sur les fouilles executées en Egypte de 1881 a 1885, „Bulletin de l'Institut Egyptien" 1885 (1886), 2. Ser. 6, s. 85.

${ }^{23}$ M.in. Paul Lucas (1664-1737); Richard Pococke (1704-1765); Alexandre-Bourges Saint-Genis (1772-1834) - obszerne cytaty na temat Achmim z relacji tych podróżników przytacza G. Maspero, Rapport à l'institut Ėgyptien sur les fouilles et travaux exécutés en Égypte pendant l'hiver de 18851886, „Bulletin de l'Institut Egyptien” 1886 (1887), 2. Ser. 7, s. 212-215, również U. Bouriant, Notes de voyage, ,Recueil de travaux relatifs à la philologie et à l'archéologie égyptiennes et assyriennes: pour servir de bullletin à la Mission Française du Caire" 1989, 11, s. 145 nn.

${ }^{24}$ Przyczyniło się do tego m.in. wzrastające w XIX w. zainteresowanie dawnym rzemiosłem artystycznym i wszelkiego rodzaju rękodziełem w związku z kryzysem „designu” wywołanym rewolucją przemysłową. Zaowocowało to podjętymi w wielu krajach reformami szkolnictwa w tym zakresie, a także powoływaniem do życia Muzeów Rzemiosła Artystycznego, Muzeów Techniczno-Przemy- 
zapoczątkowała zorganizowana w Österreichischen Museums für Kunst und Industrie (dziś MAK - Österreichisches Museum für angewandte Kunst) wystawa zabytków przywiezionych w 1882 roku do Wiednia przez Theodora Grafa (1840-1903), austriackiego producenta dywanów i kolekcjonera, a także pośrednika w handlu starożytnościami ${ }^{25}$. Tkaniny Theodora Grafa najprawdopodobniej pochodziły z nekropoli na terenie Fajum ${ }^{26}$. Największej liczby zabytków w tym początkowym okresie fascynacji tkaninami miało jednak dostarczyć już wkrótce Achmim²7.

Jak już wspomniałam, pierwszym archeologiem, który, słysząc o „,ine mummy cloths" ${ }^{28}$ znajdywanych w okolicach Achmim, rozpoczął systematyczne wykopaliska w tym miejscu, był Gaston Maspero (1846-1916). Od 1880 roku stał on na czele francuskiej misji archeologicznej w Egipcie (Institut Français d'Archéologie Orientale). Pierwszą kampanię zorganizował już w 1883 roku, jednak dopiero wykopaliska prowadzone w latach 1884-1886 zaowocowały odnalezieniem dużej liczby pochówków późnoantycznych $^{29}$. Maspero tak opisuje swoje odkrycia w raporcie z sezonu zimowego 1885-1886:

słowych itp. Placówki tego rodzaju były w tym czasie - obok prywatnych kolekcjonerów - jednym z głównych nabywców historycznych tkanin. Vide np. R. Houze, Textiles, fashion, and design reform in Austria-Hungary before the First World War, Burlington 2015.

${ }^{25}$ Katalog kolekcji Grafa (składającej się wówczas z 455 tkanin) opracował Joseph Karabacek vide idem, Katalog der Theodor Graf'schen Funde in Aegypten, Wien 1883, s. 6-51. Część kolekcji zakupiło od Grafa Österreichischen Museums für Kunst und Industrie, gdzie opracowane zostały przez Aloisa Riegla - A. Riegl, Die ägyptischen Textilfunde im K.K. Oesterreichischen Museum, Wien 1889. Wcześniej, przed przywiezieniem przez Grafa do Wiednia swojej olbrzymiej kolekcji, do Europy trafiały jedynie pojedyncze egzemplarze tkanin późnoantycznych z Egiptu, które nie wzbudzały większego zainteresowania, przyćmione fascynacją zabytkami Egiptu faraońskiego (kilka takich pojedynczych okazów tkanin przywiezionych w czasach napoleońskich, w muzeach w Paryżu, Turynie i Londynie wymienia: A.F. Kendrick, Catalogue of textiles from burying-grounds in Egypt, vol. 1: Greco-Roman period, London 1920, s. 4-5). Nota bene podobnie rzecz się miała z tzw. portretami fajumskimi, których długo zdawano się niemal nie zauważać, zanim doczekały się na rynku kolekcjonerskim momentu ogromnej popularności - „odkrył” je i wypromował mniej więcej w tym samym czasie co późnoantyczne tkaniny nie kto inny jak Theodor Graf.

${ }^{26}$ Podawane w najwcześniejszych publikacjach tkanin zakupionych przez wiedeńskie Muzeum od Grafa informacje na temat miejsca znalezienia są sprzeczne, w najnowszych opracowaniach uznaje się jednak, że najprawdopodobniej pochodziły z Fajum, choć pojawia się także Sakkara - vide C. Fluck, Findspot known: treasures from excavation sites in Egypt in the Museum für Byzantinische Kunst, Berlin, BMSAES, 2014, vol. 21, s. 4.

${ }^{27}$ C. Fluck, Akhmim as a source..., s. 211-224.

${ }^{28} \mathrm{O}$ zainteresowaniu Maspero tkaninami odnajdywanymi w Achmim wspomina w jednym ze swoich listów (z dnia 30 marca 1883 r.) amerykański egiptolog i dzienikarz Charles Edwin Wilbour: „Maspero had an idea of stopping at Ekhmeen, not to find the famous tombs which we have not yet seen but some graves where there are said to be fine mummy cloths. The old Panopolis was renowned for these and still we see the weavers along the market." - Travels in Egypt (December 1880 to May 1891): letters of Charles Edwin Wilbour, red. J. Capart, New York 1936, s. 244.

${ }^{29}$ Maspero badał okolice na północ od Achmim już wcześniej, w 1881 r., ale te pierwsze poszukiwania nie przyniosły oczekiwanego rezultatu, o czym pisze w jednym z raportów - vide G. Maspero, Sur les fouilles executées..., s. 84-85. Z kolei kampania w 1883 przyniosła odkrycia grobów głównie z epoki grecko-rzymskiej oraz kilka z czasów faraońskich - ibidem, s. 86-87. 
Na nekropoli w Achmim wykopaliska nieco się przesunęły. Dotychczas eksploatowane dzielnice dostarczały przede wszystkim mumii z epoki grecko-rzymskiej, natomiast dzielnice, które eksploatuje się obecnie, dostarczają mumii bizantyjskich i koptyjskich. Słowo „mumia” nie jest być może całkiem odpowiednie dla oznaczenia szczątków ludzkich, które napotykamy od sześciu miesięcy. Zwłoki nie są spreparowane według starożytnych metod: nie zostały ani otwarte, ani opróżnione $\mathrm{z}$ wnętrzności, ani przechowywane w natronie. Wydają się wysuszone w ogniu i są żółte, wychudłe, powykrzywiane w grymasach. Ubierano je w odświętne stroje lub szaty kapłańskie, jeśli zmarły należał do duchowieństwa, a następnie owijano w stare płótna i, kiedy taki pakunek osiągnął średni rozmiar 40-50 cm, jeszcze raz nakrywano go dobrze naciągniętym płótnem, które zszywano na końcach i z boku: całość bardziej przypomina podłużną paczkę jakichś handlowych towarów niż mumię ${ }^{30}$.

Relacja Maspero oddaje w ogólnym zarysie podstawową różnicę między tradycyjnymi egipskimi praktykami grzebalnymi a pochówkami z epoki późnoantycznej, gdy zanika zwyczaj mumifikacji, sporządzania kartonaży i sarkofagów itd. ${ }^{31}$ Zwłoki zabezpiecza się natomiast kilkoma warstwami tkanin, przy czym nie są to zwykłe płócienne bandaże, lecz stroje i tkaniny użytkowe, czasami o atrakcyjnej i bardzo cennej dekoracji. Jak pisze Maspero: „W tym czasie panowała moda na tapiserie i materiały haftowane: to, co zabierał ze sobą do grobu zmarły, mogłoby wypełnić muzealną szafę"32.

Istotnie, wykopaliska w Achmim dostarczyły wielkiej liczby tkanin na rynek kolekcjonerski. Jak pisze Cäcylia Fluck, nie ma najmniejszej wątpliwości, że większość tkanin pojawiających się na rynku antykwarycznym w latach 1885-1886 pochodziła właśnie stamtąd ${ }^{33}$. Po Maspero zjawili się w Achmim następni archeolodzy i kolekcjonerzy. Prawdopodobnie z Achmim pochodzi m.in. kolekcja tkanin zakupiona w 1886 roku przez przebywającego wówczas w Egipcie Franza Bocka (1823-1899) ${ }^{34}$, niemieckiego duchownego i kolekcjonera, zainteresowanego sztuką kościelną, a zwłaszcza szatami liturgicznymi ${ }^{35}$. Również Theodor Graf odwiedził Achmim, nabywając kolejne egzemplarze do

30 G. Maspero, Rapport à l'institut Ègyptien sur les fouilles et travaux exécutés en Égypte pendant l'hiver de 1885-1886, „Bulletin de l'Institut Egyptien” 1886 (1887), 2. Ser. 7, s. 210-211 (tłum. A.G.).

31 Więcej na temat zmian w zwyczajach pogrzebowych - vide F. Dunand, Between tradition and innovation: Egyptian funerary practices in late antiquity [w:] Egypt in the Byzantine world, 300-700, red. R.G. Bagnall, Cambridge 2007, s. 163-184; F. Dunand, R. Lichtenberg, Mummies and death in Egypt, London 2006, s. 72-93 i 123-132.

32 G. Maspero, Sur les fouilles executées..., s. 211-212 (tłum. A.G.).

33 C. Fluck, Akhmim as a source..., s. 212-213. Autorka, podobnie zresztą jak wielu innych badaczy, zaleca jednak zachowywanie dużej ostrożności w przyjmowaniu za pewnik, podawanego w dokumentacji muzealnej miejsca znalezienia tkanin i zaleca każdorazowe zweryfikowanie go. Vide również E.R. O'Connell, Representation and self-presentation in Late Antique Egypt: 'Coptic' textiles in the British Museum [w:] Textiles as cultural expressions: proceedings of the $11^{\text {th }}$ Biennial Symposium of the Textile Society of America, September 24-27, Honolulu 2008, s. 4-5.

34 F. Bock, Katalog frühchristlicher Textilfunde des Jahres 1886, Düsseldorf 1887. O achmimskim pochodzeniu tkanin Franza Bocka wspomina R. Forrer, Die Gräber- und Textilfunde von Achmim-Panopolis, Strassburg 1891 (dalej cyt.: Textilfunde), s. 9 (Einleitung); idem, Seiden, s. 9.

35 Bock jest autorem pierwszego naukowego opracowania historii szat liturgicznych, Geschichte der liturgischen Gewänder der Mittelalters, oder Entstehung und Entwicklung der kirchlichen Ornate 
swojej kolekcji ${ }^{36}$. W 1889 roku kopał tam Vladimir G. de Bock (1850-1899), którego zdobycze trafiły do Ermitażu ${ }^{37}$, i wreszcie - w 1894 roku w Achmim rozpoczął wykopaliska Forrer. Już w czasach Maspero jednocześnie z oficjalnymi pracami badawczymi ruszyła machina nielegalnych, prowadzonych przez miejscową ludność, czysto rabunkowych wykopalisk (nawiasem mówiąc, również metody stosowane wówczas podczas legalnych prac archeologicznych dziś mogą się wydawać co najmniej nieprofesjonalne) ${ }^{38}$. Wszystko to wkrótce doprowadziło do zupełnej dewastacji achmimskiej nekropoli. Urbain Bouriant (1849-1903) - bliski współpracownik Gastona Maspero, w latach 1883-1886 kurator Muzeum w Bulaq, a następnie, do 1898, dyrektor IFAO ${ }^{39}$ - tak opisuje bulwersujący i smutny widok, jaki ukazał się jego oczom, gdy w 1888 roku przybył do Achmim:

Mija właśnie pięć lat, odkąd po raz pierwszy wbiłeś kilof na nekropoli w Achmim (...). Dziś odbywa się tu prawdziwa grabież, której nie sposób powstrzymać. Wszystko jest poprzewracane, powyrywane, porozbijane (...). Nekropola koptyjska, z której pochodzą wszystkie tkaniny, jest już prawie wyczerpana ${ }^{40}$.

Proceder, który opisuje Bouriant, nieodwołalnie zaprzepaścił kontekst archeologiczny znalezisk. Nie ma właściwie nic, co moglibyśmy nazwać „dokumentacją” w dzisiejszym znaczeniu tego terminu; jedyne, czym dysponujemy, to relacje archeologów takich jak Maspero, Bouriant, a zwłaszcza Forrer, który pozostawił najbardziej szczegółowe opisy swoich odkryć - zarówno samych tkanin, jak i mumii oraz grobów, w jakich je złożono. W 1894 roku, gdy Forrer rozpoczął prace wykopaliskowe w Achmim, nekropola była już w dużym stopniu zdewastowana ${ }^{41}$. W 1895 roku ukazała się publikacja złożona z listów, które archeolog pisał podczas pobytu w Achmim do Gustava Adolfa Müllera (1866-1928), dziennikarza, z którym współredagował pismo „Antiquitäten-Zeitschrift”42. W jednym z listów Forrer odmalowuje makabryczny widok barbarzyńsko ograbionej nekropoli, z poniewierającymi się wszędzie szczątkami ludzkimi, obdartymi z tkanin i porozrzucanymi bezładnie dookoła czarnych dziur rozkopanych grobów. „Nie jest to widok dla wrażliwych ludzi” - komentuje Forrer, dodając jednak: ,ale ciekawość archeologa wysuwa się na pierwszy plan" ${ }^{43}$. Badacz szczegółowo opisuje odkryte przez siebie grobow-

und Paramente mit Rücksicht auf Stoff, Gewebe, Farbe, Zeichnung, Schnitt und rituelle Bedeutung, vol. 1-3, Bonn 1859-1871.

${ }^{36}$ C. Fluck, Akhmim as a source..., s. 213 i przyp. 12 na s. 221-222.

37 A.F. Kendrick, Catalogue..., vol. 1, s. 5.

${ }^{38} \mathrm{O}$ ówczesnych legalnych i nielegalnych procedurach pozyskiwania egipskich zabytków na handel - vide F. Hagen, K. Ryholt, The antiquities trade in Egypt 1880-1930, Copenhagen 2016.

${ }^{39}$ P. Bouriant, Notice sur Urbain Bouriant, , Recueil de travaux relatifs à la philologie et à l'archéologie égyptiennes et assyriennes: pour servir de bullletin à la Mission Française du Caire" 1904, vol. 26, s. 29-32.

${ }^{40} \mathrm{U}$. Bouriant, Notes de voyage, „Recueil de travaux relatifs à la philologie et à l'archéologie égyptiennes et assyriennes: pour servir de bullletin à la Mission Française du Caire” 1989, vol. 11, s. $140-141$.

${ }^{41}$ C. Fluck, Akhmim as a source..., s. $213 \mathrm{nn}$.

${ }^{42}$ R. Forrer, Mein Besuch im Achmim, Strassburg 1895.

${ }^{43}$ Ibidem, s. 32. 
ce, a także relacjonuje odwijanie mumii, ze znacznie większą niż Maspero pieczołowitością odnotowując wszystkie detale kolejnych warstw spowijających zwłoki tkanin ${ }^{44}$.

Forrer zgromadził olbrzymią kolekcję tekstyliów, która dostarczyła następnie eksponatów wielu muzeom, m.in. w Berlinie ${ }^{45}$, Brukseli ${ }^{46}$, Genewie ${ }^{47}$, Budapeszcie ${ }^{48}$, Würzbur$\mathrm{gu}^{49}$, Gdańsku ${ }^{50}$, Krakowie ${ }^{51}$. Zanim rozpoczął własne wykopaliska w Achmim, zakupił na rynku w Kairze pokaźną ilość tkanin (ok. 2 tysiące fragmentów), które opisał i przeanalizował w dwóch bogato ilustrowanych tomach ${ }^{52}$. Forrer próbował usystematyzować zabytki i uporządkować ich chronologię, opierając się głównie na analizie cech stylistycznych i ikonografii. Niektóre z poglądów Forrera są dziś nieaktualne, jednak jego rzetelne i skrupulatne jak na owe czasy podejście do badanego materiału znacznie ułatwiło następnym pokoleniom podjęcie dalszych badań nad poszczególnymi grupami tkanin z Achmim, a jego publikacje pozostają najcenniejszym źródłem informacji o utraconym bezpowrotnie kontekście archeologicznym ${ }^{53}$.

Do typowych achmimskich wyrobów tkackich zalicza się:

1. tkaniny użytkowe (poduszki, narzuty itp.) o długiej okrywie pętelkowej i kwadratowych tapiseryjnych wstawkach, z dekoracją składającą się z większego pola centralnego zawierającego przedstawienia figuralne (np. wojownik zabijający wroga, polowanie) i otaczających go mniejszych pól wypełnionych motywami erosów, zwierząt, roślin;

2. tapiseryjne wstawki z przedstawieniami scen biblijnych (szczególnie często historii Józefa Egipskiego);

3. interesujące nas tkaniny jedwabne ${ }^{54}$.

W znaleziskach z Egiptu rzadko spotyka się szaty wykonane w całości z jedwabiu. Tego drogiego materiału używano raczej w postaci dekoracyjnych wstawek na lnianych

44 Ibidem, s. 44-48.

45 O. Wulff, W.F. Volbach, Spätantike und koptische Stoffe aus àgyptischen Grabfunden, Berlin 1926, s. 159.

46 I. Errera, Collection d'anciennes étoffes égyptiennes, Bruxelles 1916, nr kat. 53.

47 Vide M. Martiniani-Reber, Tissus façonnés d'Achmim (Êgypte), „Genava” 1989, vol. 37, s. 19-28.

48 L. Török, op. cit., vol. 2., s. 13.

49 Vide D. Renner, Die koptischen Stoffe im Martin von Wagner Museum der Universitat Würzburg, Wiesbaden 1974, s. 1n.

50 Zakupione w latach 1890-1891 przez ówczesne Westpreussisches Provinzial-Kunstgewerbemuseum, zabezpieczone w trakcie drugiej wojny światowej, w 1947 r. przekazane zostały do zbiorów Muzeum Narodowego w Warszawie; obecnie trafiły z powrotem do Gdańska, gdzie magazynowane są w Muzeum Narodowym. Vide K. Urbaniak-Walczak, Tkaniny późnoantyczne z Egiptu, Warszawa 2003, s. 7; L. Łopuski, B. Sztyber, Tkaniny koptyjskie oraz zabytki znad Nilu i Tybru w zbiorach Muzeum Narodowego w Gdańsku, „Biuletyn Muzeum Narodowego w Gdańsku” 2014, 6, s. 30-31.

51 W 1894 r. zakupiło od Forrera ok. 30 tkanin Muzeum Techniczno-Przemysłowe - vide S.J. Gąsiorowski, op. cit., s. 237. Tkaniny te są obecnie częścią kolekcji Muzeum Narodowego w Krakowie.

${ }^{52}$ R. Forrer, Die Gräber- und Textilfunde...; idem, Die römischen und byzantinischen Seidentextilien... W 1892 r. wydał osobną publikacją, w której omawia pochodzące z Achmim różnego rodzaju obiekty rzemiosła artystycznego, w tym tkaniny, z symbolami i scenami chrześcijańskimi - idem, Die frühchristlichen Alterthümer aus dem Gräberfelde von Achmim-Panopolis, Strassburg 1892.

53 C. Fluck, Akhmim as a source..., s. 214.

54 Ibidem, s. 215-220. 
tunikach $^{55}$. Najcenniejszym przykładem zastosowania jedwabnych wstawek typowych dla Achmim jest tunika ze zbiorów Victoria and Albert Museum (nr inw. 820-1903) ${ }^{56}$. Jest ona jednym ze stosunkowo rzadkich przykładów tkaniny zachowanej w całości zazwyczaj handlarze wycinali cenne fragmenty z dekoracją (czasami tnąc je jeszcze na mniejsze fragmenty dla zwiększenia zysku), a nieatrakcyjny dla kolekcjonerów len wyrzucano. Analizując dekorację tej tuniki, można uchwycić wszystkie najważniejsze znamiona achmimskich tkanin jedwabnych, jak również zrekonstruować pierwotny wygląd i kontekst będących w kolekcji Muzeum Uniwersytetu Jagiellońskiego niewielkich zaledwie wycinków bardzo podobnej dekoracji tuniki jak ta z V\&A.

Wstawki znajdują się w trzech miejscach i obejmują trzy rodzaje elementów:

1. clavi - pasy biegnące zarówno z przodu, jak z tyłu szaty pionowo po obu stronach dekoltu i kończące się w połowie długości tuniki zaokrąglonymi sigillami;

2. orbiculi - okrągłe wstawki umieszczone poniżej clavi (dwa z przodu i dwa z tyłu tuniki);

3. szerokie prostokątne wstawki przy zakończeniach rękawów.

Achmimskie tkaniny jedwabne to przeważnie samity - dwustronne tkaniny wykonane splotem wzorzystym wątkowym w porządku skośnym ${ }^{57}$, i tak jest również w tym przypadku. Dekoracja wstawek składa się z jasnych (w kolorze niebarwionego jedwabiu) motywów na ciemnym (purpurowym) tle bądź odwrotnie - ciemnych motywów na jasnym tle. Są to głównie wyrafinowane, złożone z wielu misternie opracowanych elementów, motywy floralne - różnego rodzaju palmety, rozety, wici, zdradzające wyraźną inspirację sztuką sasanidzką. Uzupełniają je w niektórych miejscach przedstawienia figuralne.

Na clavi rozmieszczono w polach o kształcie na zmianę leżącego krótkiego prostokąta i stojącego długiego prostokąta stylizowane motywy roślinne (por. il. 1 - von Falke). W polach o kształcie leżącego prostokąta są to dwa warianty rozet zbudowanych na schemacie gwiazdy złożonej z symetrycznie rozchodzących się z centralnego punktu palmetek (w jednym z wariantów rozeta ujęta jest w okrąg, otoczony półkolami wypełnionymi kolejnymi palmetkami). W polach o kształcie stojącego prostokąta znajduje się motyw będący połączeniem wici półpalmetowej i tzw. drzewa życia, nazywanego też drzewem palmetowym"58. Składa się on z falistej, ulistnionej łodygi zwieńczonej rozbudowaną palmetą. Językowate, wydłużone i zaokrąglone na końcu liście wyginają

55 R. Forrer, Seiden, s. 10; E. Wipszycka, op. cit., s. 39.

56 Vide A.F. Kendrick, Catalogue of textiles from burying-grounds in Egypt, vol. 3: Coptic Period, London 1922, s. 74, nr kat. 794, il. na frontyspisie. Vide również wirtualny katalog Victoria and Albert Museum: http://collections.vam.ac.uk/item/O248677/tunic-unknown/ [dostęp: 14.08.2018].

${ }^{57}$ Nazwa „samit” wywodzi się od łacińskiego „examitum”, które z kolei jest pochodzenia greckie-

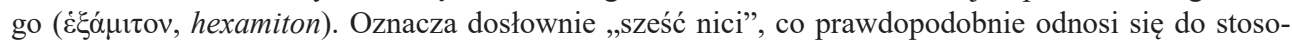
wania trzech nici w osnowie zasadniczej i trzech w osnowie wiążącej - vide J. Galliker, Terminology associated with silk in the Middle Byzantine Period. (AD 843-1204) [w:] Textile terminologies from the Orient to the Mediterranean and Europe, 1000 BC to 1000 AD, red. S. Gaspa, C. Michel, M.-L. Nosch, Lincoln 2017, s. 22.

${ }^{58}$ Takiego określenia na oznaczenie tego motywu używają m.in.: L. Török, op. cit., vol. 2, s. 39, 47. W jednym z najnowszych opracowań (A. de Moor, S. Schrenk, C. Verhecken-Lammens, op. cit.) autorzy opisują ten motyw jako „, combination of a candelabrum and a tendril” (s. 85). Th.K. Thomas (,Ornaments of excellence” from ,the miserable gains of commerce”: luxury art and Byzantine culture [w:] Byzantium and Islam: age of transition, $7^{\text {th }}-9^{\text {th }}$ century, red. H.C. Evans, B. Ratliff, New York 
się półkoliście, wypełniając zakola falującej łodygi; ułożone są po trzy od najmniejszego do największego i przypominają kształtem wachlarzowatą półpalmetę ${ }^{59}$. Po bokach z łodygi wyrastają dodatkowo na cienkich łodyżkach, ulistnionych podobnie jak główna łodyga, duże ,pąki” o łezkowatym kształcie, obramowane perełkowaniem i wypełnione w środku motywem spiętrzonych jedna nad drugą par łuków. Na szczycie łodygę wieńczy krzaczasta palmeta, występująca w dwóch wariantach. Brzegi clavi obiega wąski pas z wicią utworzoną z rzędu kielichowatych palmet, z których co druga odwrócona jest o 180 stopni („kielichy” palmet zwrócone są na zmianę w prawo i w lewo). Palmety składają się z centralnego czubka i dwóch par długich wygiętych esowato liści, z tym że zewnętrzne liście są nieco szersze i wspólne dla sąsiadujących ze sobą palmet ${ }^{60}$. Na okrągłych sigillach w zakończeniach clavi znajdują się podobne jak w prostokątnych polach, ale ujęte tutaj w okrągły medalion z wicią palmetową, ,drzewa palmetowe” i na prostej, a nie falistej łodydze, na której liście i łezkowate „pączki” rozmieszczone są według praw ścisłej symetrii.

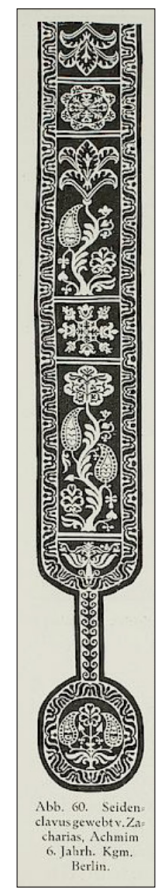

Il. 1. Schemat dekoracji typowego jedwabnego clavusa z grupy „Zachariasstoffe”. Fot. za:

O. von Falke, Kunstgeschichte der Seidenweberei, Berlin 1913, il. 60 na s. 44

2012, s. 132) wymienia inne spotykane określenia: „motif known as the candelabra tree - also called a lotus tree, a palmette tree, Tree of Life, spindly vine, and an arabesque".

${ }^{59} \mathrm{Na}$ temat tego rodzaju wici w jej najprostszych wariantach - vide P. Skubiszewski, Najstarsze dzieje wici pótpalmetowej na Wschodzie [w:] Sztuka i historia. Księga pamiątkowa ku czci profesora Michała Walickiego, red. J. Białostocki, Warszawa 1966, s. 17-21.

${ }^{60}$ Wić tę można uznać za daleko idące przetworzenie klasycznego anthemionu - na temat ewolucji motywu palmety i fryzów palmetowych w sztuce późnoantycznej - vide A. Riegl, Stilfragen: Grundlegungen zu einer Geschichte der Ornamentik, Wien 1893, s. 253-258. 
Podobne, symetryczne „drzewa palmetowe” o prostej łodydze, wpisane w medalion obramowany wicią palmetową, zdobią orbiculi. Z łodygi wyrastają na 1/3 i 2/3 jej wysokości dwie pary osiowo rozłożonych łodyżek, zwieńczonych łezkowatym motywem pąków, analogicznych ja te opisane przy okazji clavi, przy czym górne pąki mają dodatkowo w dolnej części „falbankę” z półkolistymi wcięciami. Łodyżki są przy podstawie obficie ulistnione kępkami „wąsatych”, palmetowych liści. Dodatkowo między kępkami liści z głównej łodygi wyrastają delikatne, powyginane w górę i w dół cienkie łodyżki zakończone motywami niewielkich trójliści i listków o sercowatym kształcie. Całość wieńczy palmeta złożona z gwiaździście ułożonych małych palmetek, wpisanych w kontur kwiatu o siedmiu półkolistych płatkach.

Wstawki na rękawach dekorują oprócz podobnych do wyżej opisanych motywów roślinnych dwa sąsiadujące ze sobą prostokątne pannaeux, przedzielone wąskim pasem z motywami trzech ułożonych piramidalnie kółek, wpisanych w większe koło, zwieńczone motywem przypominającym lilię. W obu pannaeux przedstawiony jest w lustrzanym odbiciu ten sam motyw: jeździec walczący z piechurem. Na ujętym w profilu galopującym koniu ukazany jest frontalnie jeździec o młodzieńczej twarzy i półdługich, falujących włosach, ubrany w zbroję i powiewający za plecami płaszcz. Jedną ręką trzyma uzdę, w drugiej, uniesionej, dzierży coś w rodzaju buławy. Przed nim unosi się z rozpostartymi skrzydłami ptak przypominający orła. Powyżej wzdłuż górnej krawędzi pola obrazowego biegnie napis $Z A X A P I O Y$ (w jednym z panneau napis, podobnie jak wszystkie inne składowe dekoracji, ukazany jest w lustrzanym odbiciu - YOIPAXAZ). W dolnej części panneux przedstawiona jest znacznie mniejsza od jeźdźca postać uzbrojonego piechura, który wbija włócznię w bok konia. Obok piechura po obu stronach rosną długie ulistnione i ukwiecone łodygi, a po zewnętrznej stronie przedstawień stoi ptak o długich nogach i długiej, pochylonej szyi (żuraw?).

Interpretacja imienia „Zachariasz”, a także pojawiającego się na niektórych tkaninach jedwabnych o podobnej dekoracji, również znalezionych w Achmim, imienia „Józef”61 jest przedmiotem dyskusji. Badacze zasadniczo dzielą się w tej kwestii na dwa obozy: tych, którzy odnoszą imiona do postaci jeźdźca i przypisują mu symboliczną wymowę ${ }^{62}$,

${ }^{61} \mathrm{~Np}$. na fragmencie w Cleveland - vide D. Sherperd, A Coptic silk, ,The Bulletin of the Cleveland Musuem of Art" 1947, vol. 34, s. 216-217, 237.

${ }^{62}$ R. Forrer (Seiden, s. 15) był zdania, że imię „Iosef” ma dookreślić jeźdźca i że chodzi z pewnością o „Józefa Patriarchę”; z kolei w napisie odczytywanym przez większość badaczy jako „ZAXARIOY” Forrer - jak sam mówi - „,chciałby przeczytać MAXAPIOY i pomyśleć o pustelniku Makarym". Interpretacja ta wydawała się Forrerowi tym bardziej kusząca, że Makary ze Sketis istotnie był jednym z najpopularniejszych w Egipcie świętych Ojców Pustyni. Ponadto imię „Makary” oznacza „błogosławiony”, co Forrer uznał za chęć zapewnienia błogosławieństwa zmarłemu. Jeszcze inną propozycję odczytania imion na tkaninach jedwabnych z Achmim - niepodjętą jednakże w późniejszych opracowaniach - przedstawiła D.G. Shepherd. Autorka uważa, że imiona te przywołują Józefa, ojca Jezusa i Zachariasza, ojca Jana Chrzciciela. Uzasadnia swój pomysł następująco: „In a fourth-century Coptic church at Deir Abu Hennis are frescoes depicting the annunciation to Zacharias of his future fatherhood. In the same series are the Warning of Joseph, and the Flight into Egypt. These representations do not seem to occur in early Christian art outside of Egypt and may indicate that Zacharias and Joseph had a special importance to the Copts, which would account for their repetition in this group of textiles. This then provides further evidence that these textiles are the products of the local workshops of Akhmim” - D.G. Shepherd, A Coptic silk, „Bulletin of the Cleveland Museum of Art” 1947, 
oraz tych, którzy uznają je po prostu za sygnatury tkaczy lub właścicieli warsztatu tkackiego ${ }^{63}$. W związku z tą drugą hipotezą w niektórych opracowaniach i katalogach w odniesieniu do pochodzących z Achmim tkanin jedwabnych o analogicznej jak opisana dekoracji używa się określenia „Zachariasstoffe” (terminem tym posłużono się też w XIX-wiecznych kartach ewidencyjnych tkanin jedwabnych w MUJ) czy „Zacharias silk”, „Zacharias style”, „Zacharias workshop"64. Fragmenty tego rodzaju tkanin - clavi, orbiculi, paneli z rękawów itd. - znajdują się w wielu europejskich i pozaeuropejskich kolekcjach $^{65}$. Na niektórych widnieją poza opisanymi wyżej także inne motywy figuralne i zoomorficzne ${ }^{66}$. Najbardziej charakterystyczną dla tej grupy dekoracją są jednak opisane powyżej formy roślinne o sasanidzkiej genezie.

„Zachariasstoffe” można podzielić na dwie grupy, z których pierwszą badacze określili mianem „organicznej” dla odróżnienia od drugiej, nazwanej „stylizowaną”, która przedstawia te same motywy w uproszczonej formie ${ }^{67}$. W ostatnich latach przy okazji gruntownych badań nad tkaninami jedwabnymi z Achmim dokonano rewizji ich datowania. Na podstawie analiz stylistycznych i ikonograficznych datowano je dotychczas najczęściej na VI wiek ${ }^{68}$. Badania przy zastosowaniu metody węglowej ${ }^{69}$ wykazały, że uśrednione granice czasowe powstania tkanin, których dekorację określono jako „organiczną", zawierają się pomiędzy połową VII a połową VIII wieku, zaś w przypadku tkanin „stylizowanych” - uśrednione datowanie to VIII-IX wiek ${ }^{70}$.

vol. 34, s. 237. Inni badacze odnoszący imiona Zachariasza i Józefa do jeźdźców to m.in.: A.F. Kendrick, Catalogue..., vol. 3, s. 76.

${ }^{63}$ O. von Falke, op. cit., s. 44 zwraca uwagę, że imiona pojawiają się czasami na fragmentach tkanin z czysto roślinną dekoracją, co podważa hipotezę, że odnoszą się do postaci jeźdźca; von Falke krytykuje również hipotezę, że mogą to być imiona właściciela tuniki - zdaniem badacza zachowanych fragmentów z napisem „Zachariasz” jest zbyt dużo jak na jednego właściciela. Spośród dzisiejszych badaczy opinię Von Falkego podziela m.in. C. Fluck, Akhmim as a source..., s. 216; eadem, „Denkt liebevoll an mich... ": Textilien mit Inschriften im Museum fur Byzantinische Kunst, Berlin [w:] Textile messages: inscribed fabrics from Roman to Abbasid Egypt, red. C. Fluck, G. Helmecke, Leiden-Boston 2006, s. 160-161.

${ }^{64}$ Np. L. Török, op. cit., vol. 2, s. 16, 37-39, 45, 65.

${ }^{65} \mathrm{~Np}$. w Berlinie, Brukseli, Genewie, Lyonie, Londynie, Nowym Jorku, Cleveland. Badacze sporządzili niedawno listę 20 fragmentów o potwierdzonej w źródłach proweniencji oraz listę 43 fragmentów o przypuszczalnej proweniencji - vide A. de Moor, S. Schrenk, C. Verhecken-Lammens, op. cit., s. 88-89. Obecnie do tej pierwszej listy dodać można tkaniny z MUJ.

${ }^{66}$ O. von Falke, op. cit., S. 59-62; C. Fluck, Akhmim as a source..., s. 217.

${ }^{67}$ Tkaniny obu grup różnią się też zastosowanymi barwnikami oraz pewnymi niuansami w splocie tkackim - vide A. de Moor, S. Schrenk, C. Verhecken-Lammens, op. cit., s. 92-94.

${ }_{68}$ Vide np. O. von Falke, op. cit., s. 44-46 i podpisy pod ilustracjami 59-62; A.F. Kendrick, Catalogue..., vol. 3, nr kat. 794-806, s. 75-78.

${ }^{69} \mathrm{Na}$ temat węglowego datowania tkanin późnoantycznych z Egiptu vide przede wszystkim: M. Van Strydonck, A. de Moor, D. Benazeth, 14C dating compared to art historical dating of Roman and Coptic textiles from Egypt, „Radiocarbon” 2004, 46, vol. 1. Baza tkanin późnoantycznych, które poddane zostały badaniu radiowęglowemu - vide http://www.textile-dates.uni-bonn.de/textile_list_ start.php?view=all [dostęp: 14.08.2018].

${ }^{70}$ A. de Moor, S. Schrenk, C. Verhecken-Lammens, op. cit., s. 91-92. Na temat kontynuacji „Zachariasstoffe" z epoce arabskiej - vide E.J. Grube, Studies in the survival and continuity of pre-muslim 
Do „organicznej” grupy „Zachariasstoffe” należą również trzy spośród sześciu tkanin jedwabnych w MUJ. Są to zbliżony do kwadratu o wymiarach ok. 26,5 cm $\times 24 \mathrm{~cm}$ fragment nr inw. MUJ 1237/4 i dwa niewielkie prostokątne fragmenty nr inw. MUJ 1237/1 (wym. ok. 12,5 cm × $8 \mathrm{~cm}$ ) i MUJ 1237/3 (wym.: ok. $18 \mathrm{~cm} \times 3,5-8,5 \mathrm{~cm}$ ).

MUJ 1237/1 i MUJ 1237/3 (il. II-III) to fragmenty clavusa z prostokątnymi polami, w które wpisane są na przemian gwiaździste rozety utworzone z palmetek i połączenie „drzew palmetowych” z wicią, a całość obramowana jest pasem z wicią z palmet obróconych na zmianę o 180 stopni. Opisane wyżej clavi tuniki w V\&A stanowią dla fragmentów z MUJ bardzo bliską analogię. Podobne fragmenty znajdziemy też np. w Brukseli i Genewie ${ }^{71}$.

Tkanina o nr inw. MUJ 1237/4 (il. I) jest mocno uszkodzona i naklejona na papier z namalowanymi akwarelą brakującymi fragmentami dekoracji. Przedstawia motyw „drzewa palmetowego" niemal identyczny jak ten, który widnieje na orbiculi z tuniki w V\& $\mathrm{A}^{72}$, ale w tym wypadku mamy do czynienia nie z orbiculusem, lecz z kwadratową wstawką (tabula) lub też fragmentem jakiejś większej tkaniny. Uznany za tabulę fragment z analogiczną dekoracją znajduje się m.in. w kolekcji Katoen Natie w Antwerpii ${ }^{73}$. Znane są też przykłady większych tkanin, na których medalion z drzewem palmetowym występuje w formie powtarzającego się wzoru, a między medalionami umieszczone są rozety, zbudowane $\mathrm{z}$ gwiaździście ułożonych palmetek ${ }^{74}$. Fragment takiej rozety widnieje również w zachowanym dolnym lewym rogu tkaniny w MUJ (i w akwarelowych uzupełnieniach brakujących rogów) oraz w rogach tkaniny z Antwerpii. Być może więc w obu przypadkach nie są to jednak tabulae, lecz kawałki pociętej przez handlarza większej tkaniny.

Oprócz opisanych trzech fragmentów w Muzeum Uniwersytetu Jagiellońskiego znajdują się jeszcze trzy inne kawałki późnoantycznych tkanin jedwabnych (il. IV-VI). Ich karty ewidencyjne nie zachowały się, jednak dawne metryczki wskazują na to, że zakupione zostały przez śląskie Kunstgewerbemuseum w latach 1891 i $1897^{75}$. Ich dekoracja składa się z innego typu ornamentów niż ,jedwabie Zachariasza”, ale wiele wskazuje na to, że jedna z nich (nr inw. MUJ 1237/2) również pochodzi z Achmim i nabyta została

traditions in Egyptian Islamic art, „Journal of the American Research Center in Egypt” 1962, vol. 1, s. $76-81$.

${ }^{71}$ Bruksela - vide I. Errera, op. cit., nr kat. 248, 246), Genewa - vide M. Martiniani-Reber, op. cit., il. 3,4 .

${ }^{72}$ Inne analogie znaleźć można m.in.: w Londynie - vide A.F. Kendrick, Catalogue..., vol. 3, nr kat. 798; w Brukseli - vide I. Errera, op. cit., nr kat. 249; w Berlinie - vide O. von Falke, op. cit., il. 60; w Cleveland - vide http://www.clevelandart.org/art/1952.102?collection_search_query=silk+egypt\&op=search\&form_build_id=form-xLWQSOOk2KuR1IuCBTgcy2VYi6oXRadiRgWXPAPllV8\&form_id=clevelandart_collection_search_form [dostęp: 14.08.2018]. Vide przyp. 62.

73 Vide A. de Moor, S. Schrenk, C. Verhecken-Lammens, op. cit., il. 1.

${ }^{74}$ Vide Jeden z takich fragmentów znajduje się w Museum of Fine Arts w Bostonie - vide M. Jenkins, The palmette tree: A study of the iconography of Egyptian lustre painted pottery, „Journal of the American Research Center in Egypt" 1968, vol. 7, il. 6; inny fragment, z Dumbarton Oak Collection w Waszyngtonie, publikuje: Th.K. Thomas, Perspectives on the wide world of luxury: Late Antique silk finds from Syria and Egypt [w:] Trade and exchange along the silk roads between Rome and China in antiquity, red. B. Hildebrandt, Oxford 2017, il. 5.22 na s. 67.

${ }_{75}$ Numery inwentarzowe MUJ i odpowiadające im numery ze starych metryczek: 1237/2 - 596: 91; 1237/5 - 101: 97; 1237/6-102: 97. 
od Forrera. Dekoracja tego fragmentu opiera się na schemacie romboidalnej siatki. Był to bardzo popularny wzór, który - podobnie jak roślinne motywy z „Zachariasstoffe” - zdaniem badaczy wywodził się z Persji ${ }^{76}$. Występuje on na tkaninach z Egiptu w rozmaitych wariantach (z użyciem motywów geometrycznych, roślinnych i zwierzęcych), które zdają się przynależeć do określonych centrów produkcji. W przypadku fragmentu MUJ 1237/2 (zakupionego przez Kunstgewerbemuseum w 1891 r.) wzór występuje w jednej z najprostszych spotykanych wersji, zbudowanej z czysto geometrycznych motywów. Zarys siatki tworzą podwójne rzędy ustawionych schodkowo względem siebie maleńkich kwadracików, tworzących jednocześnie zarysy małych rombów o schodkowych konturach. Pośrodku utworzonych przez tę siatkę pól widnieją podobne, lecz nieco większe romby, również zbudowane z szachownicowo ułożonych kwadracików (dziewięć w każdym rombie). Fragmenty identycznej tkaniny odnaleźć można m.in. w zbiorach Musée d'Art et d'Histoire w Genewie ${ }^{77}$ oraz w Musées Royaux des Arts Décoratifs w Brukseli ${ }^{78}$. W dokumentacji obu muzeów tkaniny te figurują jako pochodzące $\mathrm{z}$ Achmim, przy czym w wypadku fragmentu w Genewie występuje dodatkowa zbieżność proweniencji - zakupiony on został również od Forrera. Datowany jest na VIII-IX wiek (ze znakiem zapytania) $)^{79}$.

Pozostałe dwa fragmenty tkanin jedwabnych w MUJ (nr inw. 1237/5 i 1237/6), należące do zakupów dokonanych przez śląskie Kunstgewerbemuseum w 1897 roku, prawdopodobnie wiążą się z innym miejscem pochodzenia. Analogiczne tkaniny o udokumentowanej proweniencji, które można odnaleźć w innych kolekcjach, wskazują raczej na Antinoopolis niż Achmim ${ }^{80}$. Wymaga to jednak dalszych badań i stanowi temat na osobny artykut.

\section{Bibliografia}

Bouriant U., Notes de voyage, „Recueil de travaux relatifs à la philologie et à l'archéologie égyptiennes et assyriennes: pour servir de bullletin à la Mission Française du Caire" 1989, vol. 11, s. 193-199.

Dunand F., Between tradition and innovation: Egyptian funerary practices in late antiquity [w:] Egypt in the Byzantine world, 300-700, red. R.G. Bagnall, Cambridge 2007, s. 163-184.

Errera I., Collection d'anciennes étoffes égyptiennes, Bruxelles 1916.

Falke O. von, Kunstgeschichte der Seidenweberei, Berlin 1913.

Fluck C., Akhmim as a source of textiles [w:] Christianity and monasticism in Upper Egypt 1: Akhmim and Sohag, red. G. Gabra, H. Takla, Cairo 2008, s. 211-223.

${ }^{76}$ Vide Th.K. Thomas, Lattice-Patterned Silks [w:] Byzantium and Islam..., s. 149 n. Na temat najwcześniejszych znanych przykładów - vide A. Geijer, op. cit., s. 3-36; D. Thompson, The evolution of two traditional Coptic tape patterns: further observations on the classification of Coptic textiles, „Journal of the American Research Center in Egypt” 1986, vol. 23, s. 145-146.

${ }_{77}$ M. Martiniani-Reber, op. cit., il. 8.

${ }^{78}$ I. Errera, op. cit., nr kat. 387, 388.

${ }^{79}$ M. Martiniani-Reber, op. cit., s. 28.

${ }^{80}$ Vide np. O. von Falke, op. cit., il. 32 (podpisany: „Seidenstoffe mit offenen Rautenmustern aus Antinoe. Kgm. Berlin"); I. Errera, op. cit., nr kat. 372. 
Fluck C., Findspot known: Treasures from excavation sites in Egypt in the Museum für Byzantinische Kunst, Berlin, BMSAES 2014, vol. 21, s. 1-30.

Fluck C., Helmecke G., Egypt's post-pharaonic textiles [w:] Coptic civilization: two thousand years of Christianity in Egypt, red. G. Gabra, Cairo 2012.

Forrer R., Die frühchristlichen Alterthümer aus dem Gräberfelde von Achmim-Panopolis, Strassburg 1892.

Forrer R., Die römischen und byzantinischen Seidentextilien aus dem Gräberfelde von Achmim-Panopolis. Strassburg 1891.

Forrer R., Mein Besuch im Achmim, Strassburg 1895.

Galliker J., Terminology associated with silk in the Middle Byzantine Period. (AD 843-1204) [w:] Textile terminologies from the Orient to the Mediterranean and Europe, 1000 BC to 1000 $A D$, red. S. Gaspa, C. Michel, M.-L. Nosch, Lincoln 2017, s. 346-373.

Gąsiorowski S.J., Późnohellenistyczne i wczesnochrześcijańskie tkaniny egipskie w zbiorach polskich, „Prace Komisji Historii Sztuki PAU” 1928, z. 4, s. 231-292.

Geens K., Panopolis, a Nome Capital in Egypt in the Roman and Byzantine Period (ca. AD 200-600), Leuven 2014.

Geijer A., A silk from Antinoe and Sasanian textile art, „Orientalia Suecana” 1963, vol. 12, s. 3-36.

Grube E.J., Studies in the survival and continuity of pre-muslim traditions in Egyptian Islamic art, „Journal of the American Research Center in Egypt” 1962, vol. 1, s. 75-97.

Hoskins N.A., The Coptic Tapestry Albums and the archaeologist of Antinoé, Albert Gayet, Seattle-London 2004.

Jenkins M., The palmette tree: A study of the iconography of Egyptian lustre painted pottery, „Journal of the American Research Center in Egypt” 1968, vol. 7, s. 119-120.

Kendrick A.F., Catalogue of textiles from burying-grounds in Egypt, vol. 3: Coptic Period, London 1922.

Kuhlman N., Materialien zur Archäologie und Geschichte des Raumes von Achmim, SDAIK 11, 1983, s. 50-86.

Leclerq H., Akhmin [w:] DACL, t. I, cz. 1, Paris 1907, kol. 1042-1046.

Martiniani-Reber M., Tissus façonnés d'Achmim (Êgypte), „Genava” 1989, vol. 37, s. 19-28.

Maspero G., Rapport à l'institut Ègyptien sur les fouilles et travaux exécutés en Égypte pendant l'hiver de 1885-1886, „Bulletin de l'Institut Egyptien” 1886 (1887), 2. Ser. 7, s. 196-251.

Maspero G., Sur les fouilles executées en Egypte de 1881 a 1885, „Bulletin de l'Institut Egyptien” 1885 (1886), 2. Ser. 6., s. 3-91.

Moor A. de, Schrenk S., Verhecken-Lammens C., New research on the so-called Akhmim Silks [w:] Texiles in situ: Their find Spots in Egypt and neighbouring countries in the First Millennium, red. S. Schrenk, Riggisberg 2006, s. 85-94.

O'Connell E.R., Representation and self-presentation in Late Antique Egypt: 'Coptic' textiles in the British Museum [w:] Textiles as cultural expressions: proceedings of the $11^{\text {th }}$ Biennial Symposium of the Textile Society of America, September 24-27, Honolulu 2008.

Ostrowski J.A., Antyczne tkaniny znad Nilu w zbiorach Uniwersytetu Jagiellońskiego [w:] Egipt, Grecja, Italia... Zabytki starożytne z dawnej kolekcji Gabinetu Archeologicznego Uniwersytetu Jagiellońskiego, red. J. Śliwa, Kraków 2007, s. 188-192.

Pfister R., Le Rôle de l'Iran dans les textiles d'Antinoé, „Ars Islamica” 1948, vol. 13, s. 46-74.

Schnitzler B., Robert Forrer (1866-1947), Archéologue et antiquaire, Strasbourg 1999.

Sherperd D., A Coptic silk, „The Bulletin of the Cleveland Musuem of Art” 1947, vol. 34, s. 316-317.

Stauffer A., Textiles of late Antiquity, New York 1995.

Thomas Th.K., Egyptian art of late antiquity [w:] A companion to ancient Egypt, red. A.B. Llloyd, New York 2010, s. 1033-1065. 
Thompson D., The evolution of two traditional Coptic tape patterns: further observations on the classification of Coptic textiles, „Journal of the American Research Center in Egypt” 1986, vol. 23, s. 145-156.

Thomas Th.K., From curiosities to objects of art: modern reception of Late Antique Egyptian textiles as reflected in Dikran Kelekian's Textile Album of ca. 1910 [w:] Anathemata eortika: studies in honor of Thomas F. Mathews, red. J. Alhermes, Mainz 2009, s. 306-317.

Thomas Th.K., Lattice-Patterned Silks [w:] Byzantium and Islam: age of transition, $7^{\text {th }}-9^{\text {th }}$ century, red. H.C. Evans, B. Ratliff, New York 2012, s. 149-151.

Thomas Th.K., ,Ornaments of excellence” from ,the miserable gains of commerce”: luxury art and Byzantine culture [w:] Byzantium and Islam: age of transition, $7^{\text {th }}-9^{\text {th }}$ century, red. H.C. Evans, B. Ratliff, New York 2012, s. 124-134.

Wipszycka E., L'industrie textile dans l'Egypte romaine, Wrocław 1965.

Wulff O., Volbach W.F., Spätantike und koptische Stoffe aus àgyptischen Grabfunden, Berlin 1926. 



\section{Anna Głowa}

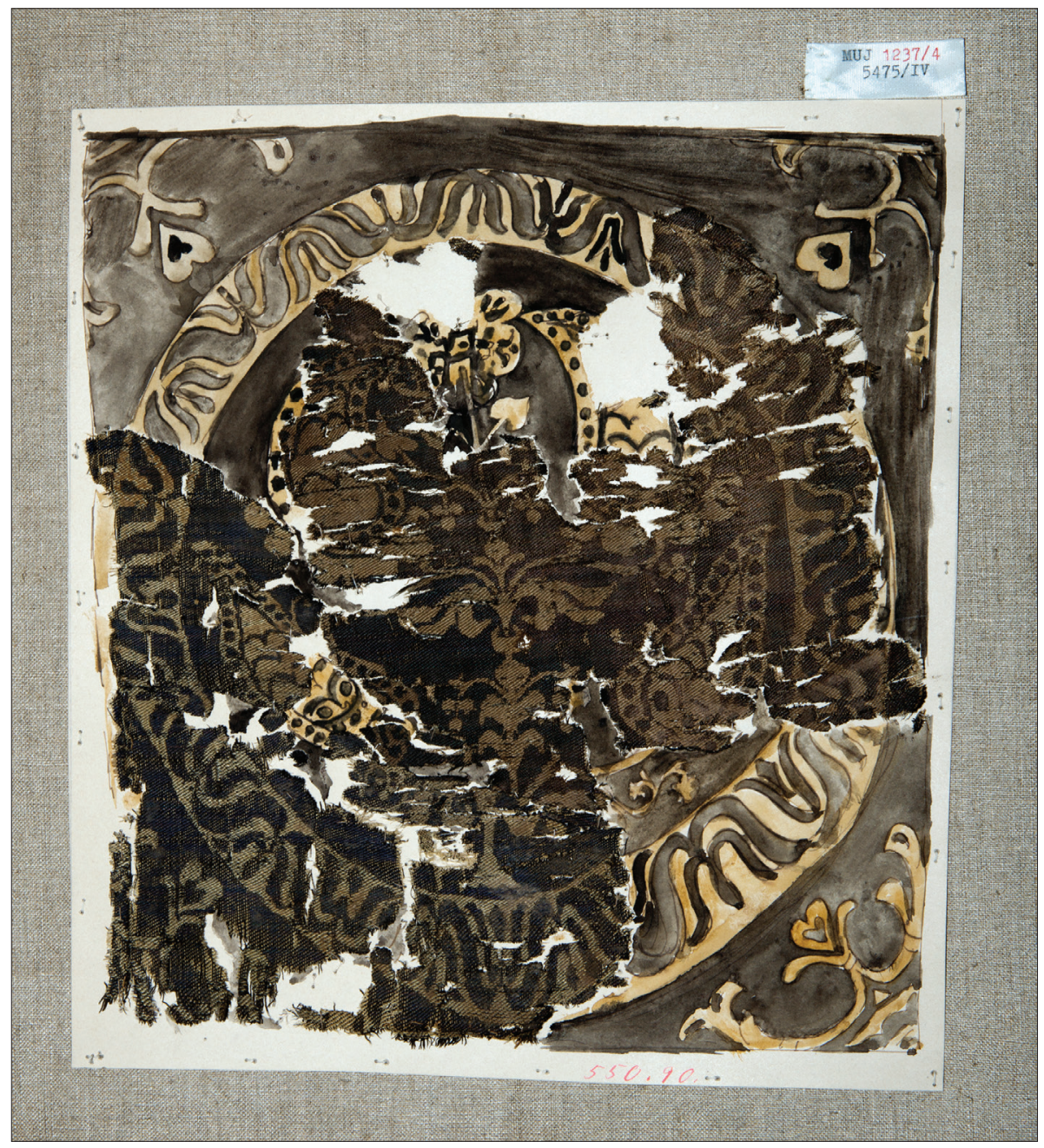

Il. I. Fragment jedwabnej tkaniny z Achmim w Egipcie w zbiorach Muzeum Uniwersytetu Jagiellońskiego (nr inw. MUJ 1237/4), VII-IX w., wym. ok. 26,5 cm × 24 cm (C) Muzeum Uniwersytetu Jagiellońskiego. Fot. J. Kozina 


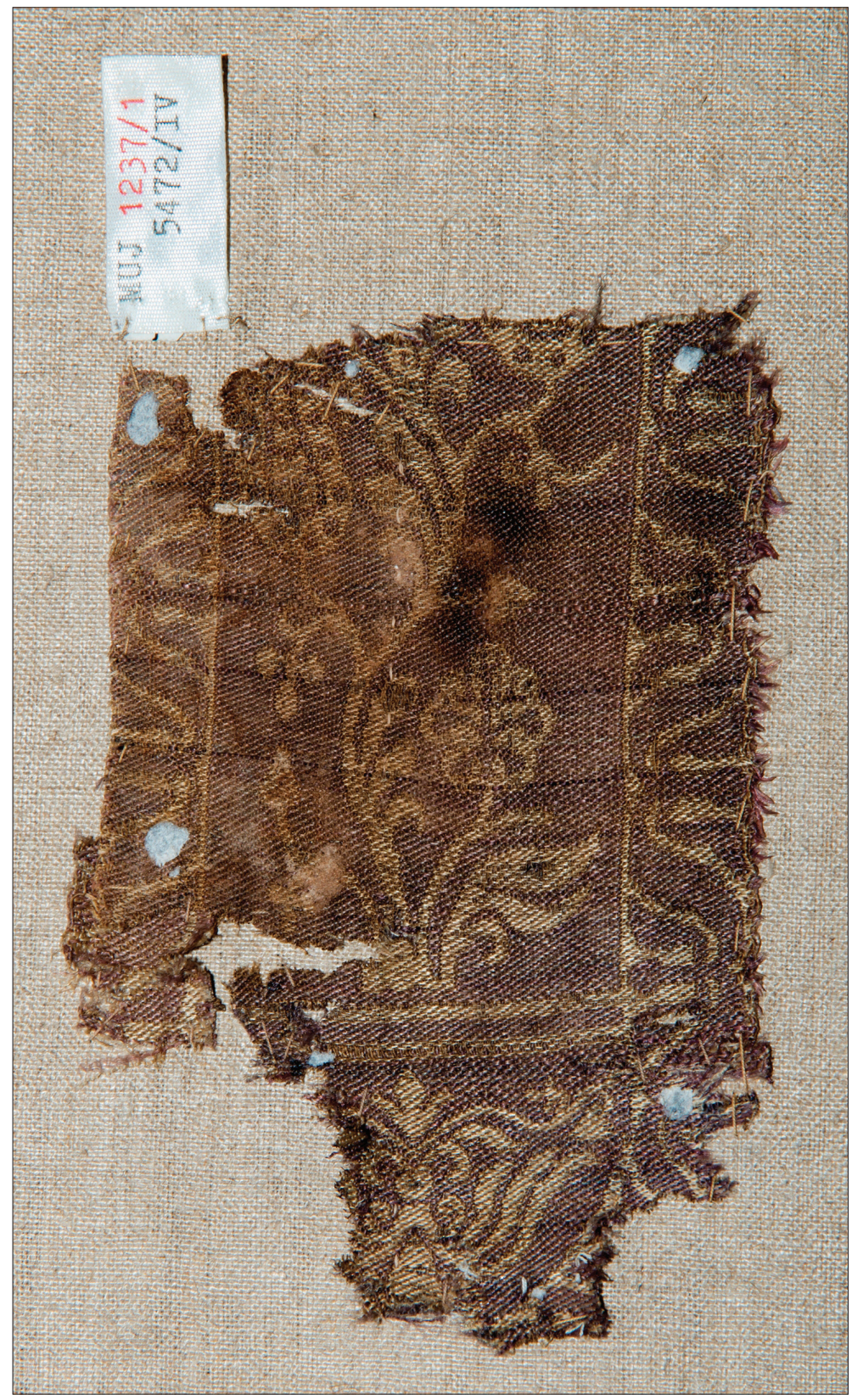

Il. II. Fragment jedwabnej tkaniny z Achmim w Egipcie w zbiorach Muzeum Uniwersytetu Jagiellońskiego (inw. MUJ 1237/1), VII-X w., wym. ok. 12,5 cm $\times 8$ cm C Muzeum Uniwersytetu Jagiellońskiego. Fot. J. Kozina 


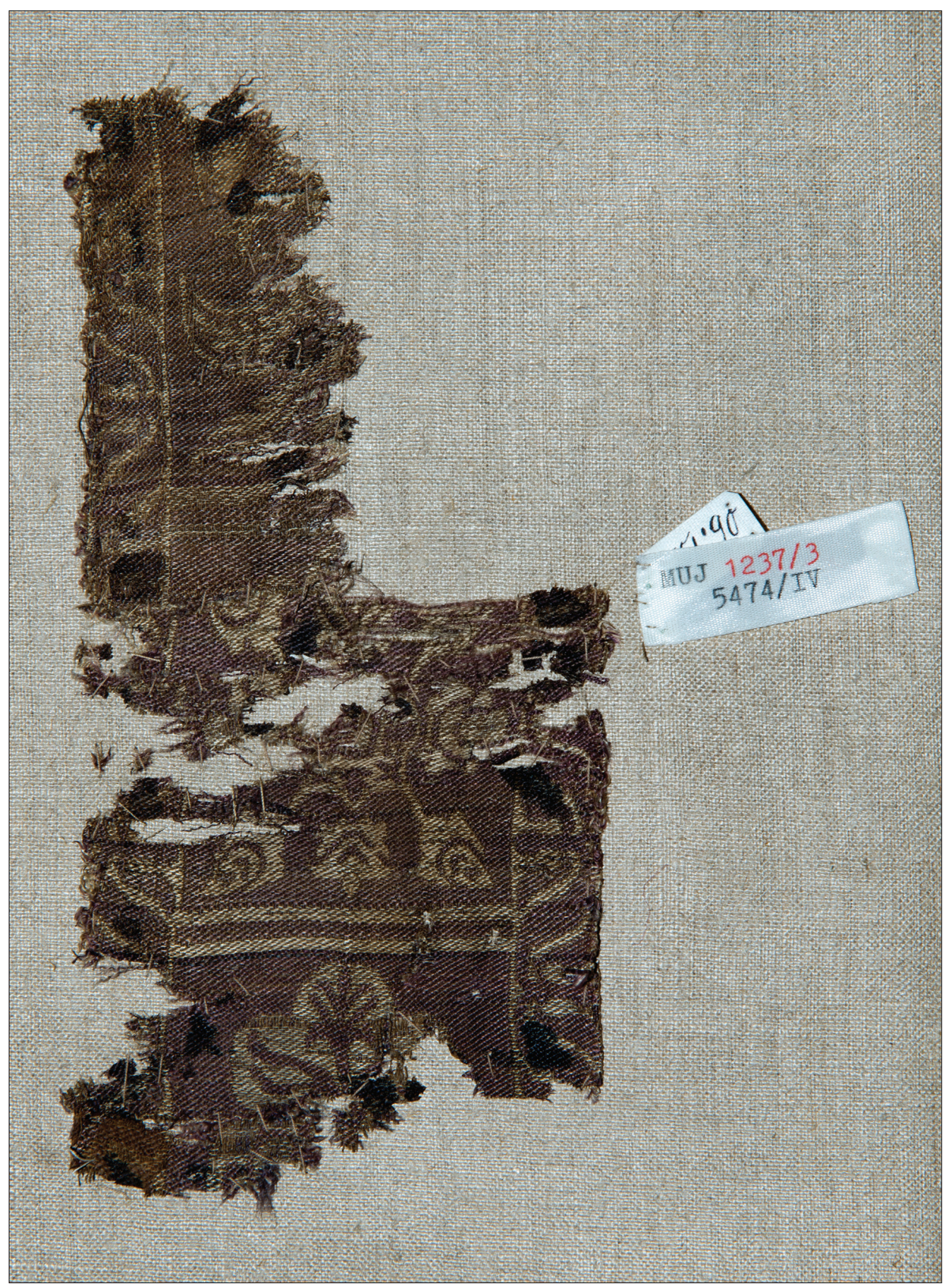

Il. III. Fragment jedwabnej tkaniny z Achmim w Egipcie w zbiorach Muzeum Uniwersytetu Jagiellońskiego (nr inw. MUJ 1237/3), VII-IX w., wym. ok. $18 \mathrm{~cm} \times 3,5-8,5 \mathrm{~cm}$ C Muzeum Uniwersytetu Jagiellońskiego. Fot. J. Kozina 


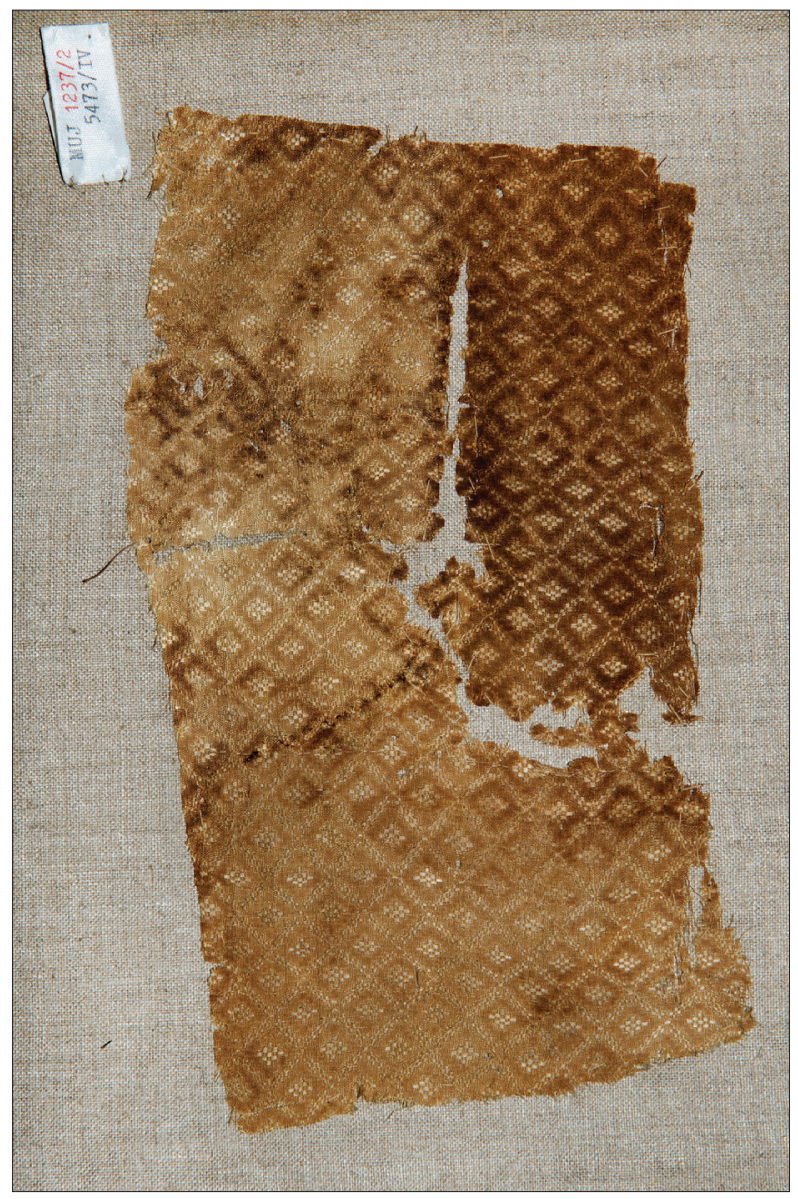

Il. IV. Fragment jedwabnej tkaniny z Egiptu (prawdopodobnie z Achmim) w zbiorach Muzeum Uniwersytetu Jagiellońskiego (nr inw. MUJ 1237/2), VIII-IX w. (?), wym.: ok. $12 \mathrm{~cm} \times 12,5 \mathrm{~cm}$ (C) Muzeum Uniwersytetu Jagiellońskiego. Fot. J. Kozina 


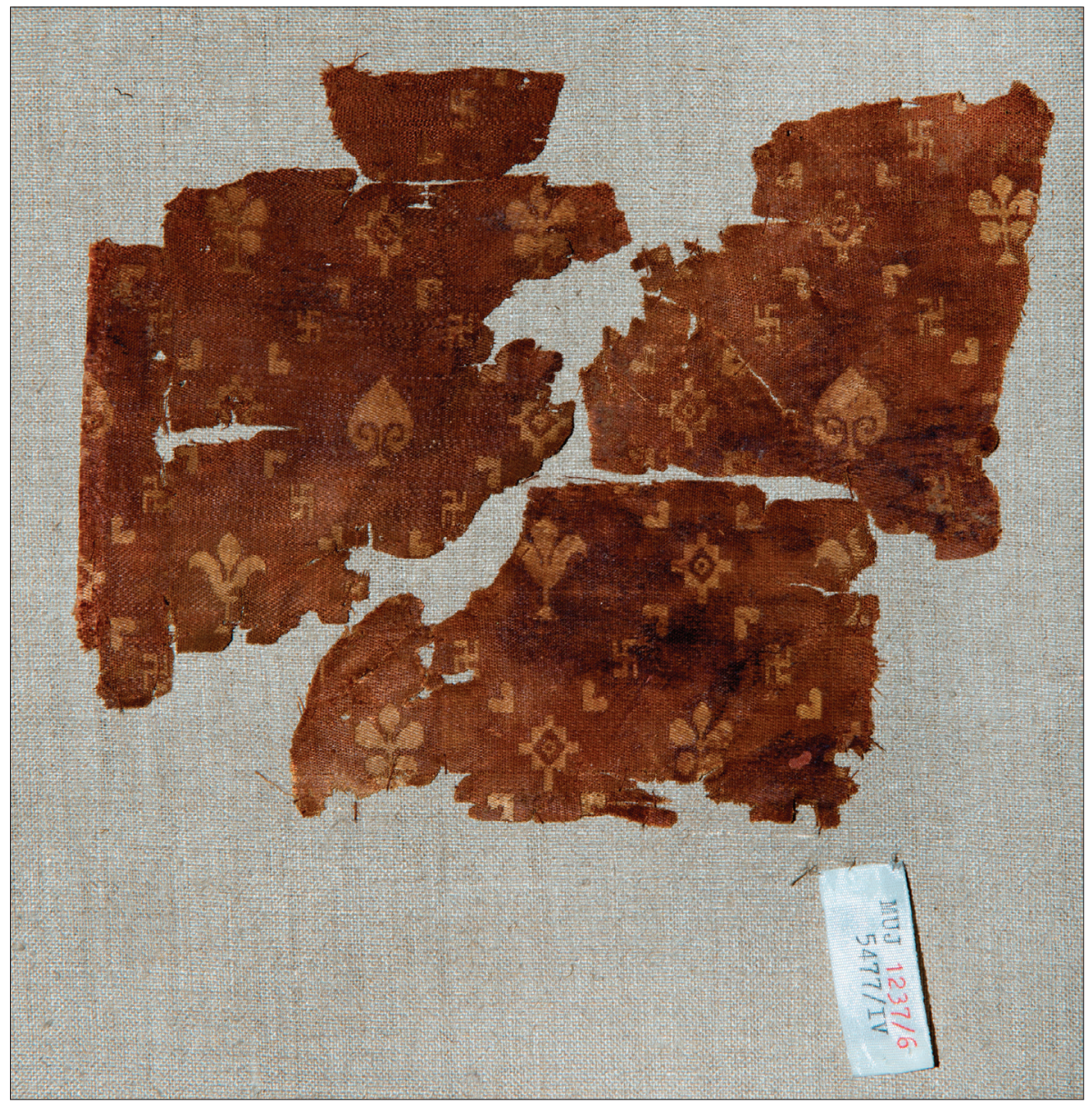

Il. V. Fragment jedwabnej tkaniny z Egiptu w zbiorach Muzeum Uniwersytetu Jagiellońskiego ( $\mathrm{nr}$ inw. MUJ 1237/6), wym.: ok. $12 \mathrm{~cm} \times 16 \mathrm{~cm}$ (C) Muzeum Uniwersytetu Jagiellońskiego. Fot. J. Kozina

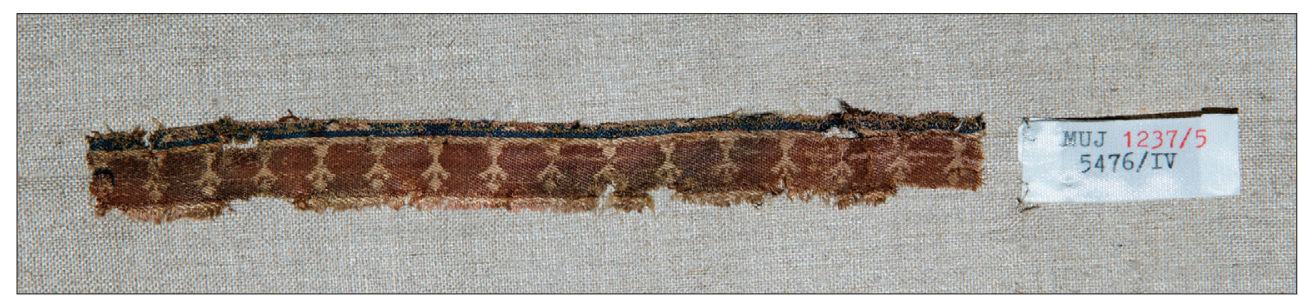

Il. VI. Fragment jedwabnej tkaniny z Egiptu w zbiorach Muzeum Uniwersytetu Jagiellońskiego (nr inw. MUJ 1237/5), wym.: ok. $16 \mathrm{~cm} \times 1,5 \mathrm{~cm}$ (C) Muzeum Uniwersytetu Jagiellońskiego. Fot. J. Kozina 